\title{
The amount of carbon in the undergrowth biomass of main types of forests stands in Poland
}

\author{
Stawomir Janyszek ${ }^{1} \bowtie$, Pawet Strzelińnki ${ }^{2}$, Magdalena Janyszek ${ }^{1}$, Dorota Wrońska-Pilarek ${ }^{2}$ \\ ${ }^{1}$ Poznań University of Life Sciences, Faculty of Horticulture and Landscape Architecture, Wojska Polskiego 71 C, \\ 60-625 Poznań, Poland, e-mail: sjan@up.poznan.pl \\ ${ }^{2}$ Poznań University of Life Sciences, Faculty of Forestry, Wojska Polskiego 71 C, 60-625 Poznań, Poland
}

\section{Abstract}

The sequestration of carbon in biomass of herb and moss layers of forest ecosystems is relatively less studied, than analogical processes in trees biomass and soil organic mass. The paper presents mean values of carbon concentration and mean amounts of dry mass of plant material in the herb and moss layer of phytocoenoses formed under canopy of stands of main forest-forming species of trees in Poland. The parameters were studied for beech, birch, oak, alder, pine, fir and spruce forest stands, for most of the particular age classes. The studied plots were contained in following plant associations and communities: Ribo nigri-Alnetum, Fraxino-Alnetum, Galio odorati-Fagetum, Luzulo luzuloidis-Fagetum, Molinio caeruleae-Quercetum roboris, Calamagrostio-Quercetum petraeae, Abietetum polonicum, Abieti-Piceetum montanum, Calamagrostio villosae-Piceetum, as well as anthropogenic communities: Betula pendula comm. on Leucobryo-Pinetum habitat, Larix decidua comm. on Tilio-Carpinetum habitat, Pinus sylvestris comm. on Tilio-Carpinetum habitat, Picea abies comm. on Luzulo pilosae-Fagetum habitat (in lowland) and Picea abies comm. on Luzulo luzuloidis-Fagetum habitat (in lower mountain localities). The relatively highest carbon amount was observed in oak forests, pine forests and in older age classes of lowland beech forest, where the carbon concentration in dry mass reaches from 60 to $81 \%$. The lowest concentrations were determined for lowland spruce forests, highland fir forests and for alder forests. The carbon concentration reached in these types of ecosystems from 39 to $41 \%$.

\section{KeY WORDS}

carbon sequestration, understory biomass, forest vegetation

\section{INTRODUCTION}

Carbon sequestration in forests phytocoenoses is a dynamic process. The biomass of plants, other living organisms and litter gradually accumulates carbon during long time of growth and keeps it enclosed in-situ until eventual harvesting or natural disturbance. Thus, forests perform an extremely important role in the global carbon cycle (Johnson and Sharpe 1983; Turner et al.1995; Zeller and Nikolov 2000; Linder et al. 2002; Nikolov and Zeller 2003).

The binding of atmospheric carbon by forest ecosystems is an important factor in the global carbon balance and has been studied on a local, regional, national 
or continental level (Karjalainen 1996; Nabuurs et al. 1997; Shepashenko et al. 1998; Apps et al. 1999; Bhatti et al. 2002; Karjalainen et al. 2002, 2003; Kurbanov and Post 2002; Cannell 2003). The overall carbon balance of forest ecosystems in Poland was made by Galiński (1995). However, the problem of carbon accumulated by undergrowth vegetation is treated marginally in existing literature. Little interest in this component probably stems from the fact that herbaceous plants, mosses and lichens accumulate very small part of the total mass of carbon contained in forest ecosystems. According to Pussinen et al. (1997), more than 50\% of the total weight of carbon is accumulated by trees, about one third - by the organic matter in the soil and about $10 \%$ by forest litter. The share of carbon accumulated in the herbs and moss layer is estimated at approximately $1-2 \%$ (Pussinen et al. 1997). However, these estimates were based on model simulation. In real ecosystems biomass of herb and moss layer, and thus the carbon concentration per unit area can vary widely as a result of forest dynamics and disturbances caused by forestry operations or natural catastrophes. In extreme cases - in highly degraded forests, under sparse canopy of trees, undergrowth biomass can reach amounts many times larger than average biomass of undergrowth in certain types of habitats. For this reason, omitting the herbs and moss biomass in estimations of total mass of carbon accumulated by the forest ecosystem can cause major inaccuracies (Muukkonen 2006).

The content of basic chemical components, including carbon, in the undergrowth of selected types of forests in north-eastern Poland were studied in the past by the group of Polish authors. These works concern especially: wet pine forest Vaccinio myrtilli-Pinetum, and subcontinental pine forest Peucedano-Pinetum (Banaszuk 1996; Banaszuk and Matowicka 1996), swamp alder forests Carici elongatae-Alnetum (Czerwiński and Pracz 1995a; Pasternak-Kuśmierska and Kotowska 1995; Pasternak-Kuśmierska and Traczyk 1995b), subcontinental oak-hornbeam forest Tilio-Carpinetum (Czerwiński and Pracz 1995b; Pasternak-Kuśmierska and Traczyk 1995a), boreal spruce forest Sphagno girgensohnii-Piceetum (Czerwiński and Pracz 1995c; Kotowska 1995) and bog forest Vaccinio uliginosi-Pinetum (Czerwiński and Pracz 1995d; Dyguś and Traczyk 1995). These studies have been realized in phytocoenoses representing the optimal phase of development of a forest, so allow comparison only among optimally developed stages of studied communities.

The aim of this paper is to present more detailed values of biomass per unit area and carbon concentration in in the undergrowth of different types of forest stands commonly occurring in Poland.

\section{MATERIAL AND METHOdS}

The study was a part of a larger project aiming at determining the accumulation of carbon in forest stands of main forest tree species in Poland. Therefore, test areas used in this study were selected on the basis of the dendrological criteria, in a way allowing to study single-species stands having parameters most often occurring in forests in Poland. Due to such criteria, only a part of studied phytocoenoses could be classified as well-developed patches of phytosociological forest associations, and mainly for these types of communities, which were characterized by canopy formed by only one tree species. Such situation occurred in cases of beech, fir, pine on poor habitats, and oak stands. For other species, the areas represented either distorted form of a particular plant community (e.g. areas with pines on fertile sites representing distorted patches of Tilio-Carpinetum), or artificial communities on the habitat of a variety of forest (e.g. birch stands on habitats of pine). In the case of alder stands the study plots were situated in two different types of forest - ash and alder riparian forest Fraxino-Alnetum and swamp alder forest Ribo nigri-Alnetum, which represented communities with significantly different habitat conditions and species composition.

The location and description of studied areas is presented in Table 1 and Figure 1.

In order to estimate the carbon content of a specific portion of forest undergrowth two parameters are needed: the concentration of carbon in plants and the mass of the plants per unit area.

The concentration of carbon was studied on samples collected in plots designated under the single-species tree stands in different 20-year age classes, up to the age over 80 years. For each tree stand, six $1.0 \times 0.5 \mathrm{~m}$ plots were chosen. The plots were selected in a way to capture all physiognomic types of floor vegetation present on the test area. For each plot, the percentage cover 
Table 1. Data on location and habitat conditions of studied areas

\begin{tabular}{|c|c|c|}
\hline Species & Forest district & Type of plant community \\
\hline \multirow{3}{*}{ Beech Fagus sylvatica (mountain habitats) } & Świeradów & \multirow{3}{*}{ Luzulo luzuloidis-Fagetum } \\
\hline & Szklarska Poręba & \\
\hline & Śnieżka & \\
\hline Beech Fagus sylvatica (lowland habitats) & Gryfino & Galio odorati-Fagetum \\
\hline Birch Betula pendula & Wronki & Birch community on Leucobryo-Pinetum habitat \\
\hline Oak Quercus petraea (poor habitat) & Zielonka & Calamagrostio-Quercetum petraeae \\
\hline Oak Quercus petraea (rich habitat) & Piaski & Molinio caeruleae-Quercetum roboris \\
\hline Fir Abies alba & Zagnańsk & Abietetum polonicum \\
\hline Larch Larix decidua & Rogów & Larch community on Tilio-Carpinetum habitat \\
\hline \multirow{3}{*}{ Black alder Alnus glutinosa } & Syców & \multirow{2}{*}{ Fraxino-Alnetum } \\
\hline & Antonin & \\
\hline & Siemianice & Ribo nigri-Alnetum \\
\hline Scots pine Pinus sylvestris (rich habitat) & Rogów & Pine community on Tilio-Carpinetum habitat \\
\hline Scots pine Pinus sylvestris (poor habitat) & Niedźwiady & Leucobryo-Pinetum \\
\hline Spruce Picea abies (submountain habitat) & Świeradów & Abieti-Piceetum montanum \\
\hline Spruce Picea abies (lower mountain habitat) & Śnieżka & Abieti-Piceetum montanum \\
\hline Spruce Picea abies (upper mountain habitat) & Szklarska Poręba & Calamagrostio villosae-Piceetum \\
\hline Spruce Picea abies (lowland habitat) & Kartuzy & Luzulo pilosae-Fagetum \\
\hline
\end{tabular}

of plant stems and leaves was noted. All the above- and belowground parts of plants in undergrowth were collected. The root systems were carefully dug out up to the depth of $50 \mathrm{~cm}$. After transportation to the laboratory, the samples were dried to a constant weight at $65^{\circ} \mathrm{C}$ temperature, weighted and pulverized in the MikroFeinmühle-Culatti MFC grinder (IKA $®$-Labortechnik Staufen, Janke \& Kunkel GmbH \& Co KG, Germany). The concentration of carbon in the biomass was measured using the Elemental Combustion System analyzer (model ECS CHNS-O 4010; Costech Instruments, Italy/ USA) in the Institute of Dendrology of Polish Academy of Sciences in Kórnik.

For each studied forest stand the mean and standard deviation of carbon concentration was calculated based on values from six plots. Additionally, on the basis of data concerning of percentage cover of analyzed plant layer in particular plots, the amount of dry mass of collected plants in one percent of cover for each particular plots were calculated, and mean values of such parameter for particular types and ages of forest stands were also computed. Having this data, one can easily calculate the amount of carbon on any given plot, multiplicat- ing presented index by area of the plot and mean percent coverage of undergrowth on the plot.

The calculations were performed using Microsoft Excell 2007 with the standard statistical plugin.

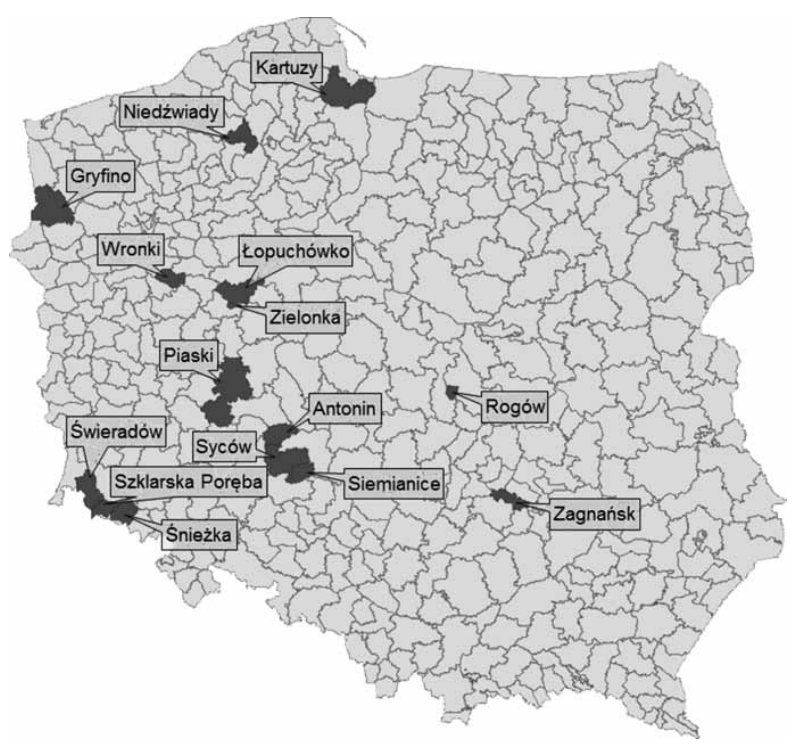

Figure 1. Location of forest districts with selected study areas overlaid on the map of Poland 


\section{Results AND DISCUSSION}

The results of the study, containing mean values of carbon amount in dry mass of herb and moss layer in certain types of forest-stands in particular age classes are shown in Table 2.

Table 2. The concentration of carbon in the dry mass of plants from herb and moss layer in phytocoenoses under main forest-forming species of trees in Poland

\begin{tabular}{|c|c|c|c|c|c|}
\hline \multirow{2}{*}{$\begin{array}{c}\text { Species of tree } \\
\text { Plant } \\
\text { association } \\
\text { Forest type }\end{array}$} & \multirow[t]{2}{*}{$\begin{array}{l}\text { Age } \\
\text { class }\end{array}$} & \multicolumn{2}{|c|}{$\begin{array}{c}\text { Carbon } \\
\text { concentration } \\
{[\% \text { dry mass }]}\end{array}$} & \multicolumn{2}{|c|}{$\begin{array}{l}\text { Dry mass of } \\
\text { plants per } 1 \mathrm{~m}^{2} \\
\text { and } 1 \% \text { of } \\
\text { plant cover }[\mathrm{g}]\end{array}$} \\
\hline & & Mean & $\begin{array}{l}\text { Std. } \\
\text { dev }\end{array}$ & Mean & $\begin{array}{l}\text { Std. } \\
\text { dev }\end{array}$ \\
\hline 1 & 2 & 5 & & 5 & 6 \\
\hline \multirow{6}{*}{$\begin{array}{l}\text { Beech Fagus } \\
\text { sylvatica (low- } \\
\text { land habitats) } \\
\text { Galio odorati- } \\
\text { Fagetum } \\
\text { Broadleaf } \\
\text { forest }\end{array}$} & I & 51.85 & 24.127 & 1.1999 & 1.1045 \\
\hline & II & 40.06 & 0.883 & 2.4737 & 2.2299 \\
\hline & III & 71.57 & 32.248 & 0.7401 & 0.4053 \\
\hline & IV & 60.67 & 31.252 & 1.4098 & 1.7751 \\
\hline & V & 60.51 & 31.379 & 0.7201 & 0.2919 \\
\hline & VI & 72.43 & 31.300 & 1.7477 & 2.1518 \\
\hline \multirow{6}{*}{$\begin{array}{l}\text { Beech Fagus } \\
\text { sylvatica } \\
\text { (mountain } \\
\text { habitats) } \\
\text { Luzulo } \\
\text { luzuloidis- } \\
\text { Fagetum } \\
\text { Mixed broad- } \\
\text { leaf forest }\end{array}$} & I & 45.02 & 1.378 & 1.5344 & 1.2816 \\
\hline & II & 44.75 & 2.437 & 2.6750 & 3.2484 \\
\hline & III & 46.14 & 1.198 & 1.7682 & 2.5252 \\
\hline & IV & 41.73 & 2.985 & 1.9175 & 1.6187 \\
\hline & V & 45.44 & 0.677 & 2.3184 & 1.8881 \\
\hline & VI & 44.04 & 0.739 & 2.6325 & 2.1612 \\
\hline \multirow{5}{*}{$\begin{array}{l}\text { Birch } \\
\text { Betula pen- } \\
\text { dula comm. } \\
\text { on Leucobryo- } \\
\text { Pinetum } \\
\text { habitat } \\
\text { Coniferous } \\
\text { forest }\end{array}$} & I & 45.30 & 0.785 & 3.7056 & 1.5406 \\
\hline & II & 44.22 & 1.880 & 1.4923 & 0.6970 \\
\hline & III & 43.98 & 1.549 & 3.0309 & 1.8894 \\
\hline & IV & 45.87 & 0.959 & 3.9485 & 1.4891 \\
\hline & V & 44.28 & 2.482 & 1.3056 & 1.0077 \\
\hline \multirow{6}{*}{$\begin{array}{l}\text { Oak Quercus } \\
\text { petraea (poor } \\
\text { habitat) } \\
\text { Calamagros- } \\
\text { tio-Quercetum } \\
\text { petraeae } \\
\text { Mixed broad- } \\
\text { leaf forest }\end{array}$} & I & 64.18 & 28.554 & 1.5539 & 1.2560 \\
\hline & II & 63.01 & 29.444 & 1.4146 & 1.2368 \\
\hline & III & 71.38 & 32.451 & 0.6362 & 0.4074 \\
\hline & IV & 61.81 & 33.944 & 2.1280 & 0.7476 \\
\hline & $\mathrm{V}$ & 81.51 & 33.765 & 1.9841 & 0.0294 \\
\hline & VI & 62.78 & 29.632 & 1.6349 & 1.1516 \\
\hline
\end{tabular}

\begin{tabular}{|c|c|c|c|c|c|}
\hline 1 & 2 & 3 & 4 & 5 & 6 \\
\hline \multirow{6}{*}{$\begin{array}{l}\text { Oak Quercus } \\
\text { petraea (rich } \\
\text { habitat) } \\
\text { Molinio } \\
\text { caeruleae- } \\
\text { Quercetum } \\
\text { roboris } \\
\text { Wet mixed } \\
\text { broadleaf } \\
\text { forest }\end{array}$} & I & 63.92 & 32.135 & 1.9684 & 1.6732 \\
\hline & II & 56.55 & 29.653 & 1.4768 & 0.9372 \\
\hline & III & 62.85 & 29.561 & 1.0091 & 0.2266 \\
\hline & IV & 44.80 & 0.572 & 3.8367 & 1.4911 \\
\hline & $\mathrm{V}$ & 55.24 & 25.601 & 1.4519 & 0.5565 \\
\hline & VI & 63.89 & 28.753 & 3.1400 & 1.6797 \\
\hline \multirow{6}{*}{$\begin{array}{l}\text { Fir Abies alba } \\
\text { Abietetum } \\
\text { polonicum } \\
\text { Mixed conif- } \\
\text { erous forest } \\
\text { - highland } \\
\text { type }\end{array}$} & $\mathrm{I}$ & 44.16 & 2.400 & 0.4007 & 0.3942 \\
\hline & II & 43.30 & 2.466 & 1.1970 & 0.9799 \\
\hline & III & 40.35 & 4.518 & 0.8709 & 0.7264 \\
\hline & IV & 43.15 & 2.267 & 2.2040 & 2.3230 \\
\hline & $\mathrm{V}$ & 43.87 & 2.480 & 0.7899 & 0.3576 \\
\hline & VI & 42.85 & 0.758 & 2.1289 & 2.2268 \\
\hline \multirow{5}{*}{$\begin{array}{l}\text { Larch Larix } \\
\text { decidua } \\
\text { comm. on } \\
\text { Querco-Pine- } \\
\text { tum, (I-II) and } \\
\text { Tilio-Carpine- } \\
\text { tum habitats } \\
\text { Mixed conif- } \\
\text { erous forest } \\
\text { Mixed broad- } \\
\text { leaf forest }\end{array}$} & I-II & 42.55 & 0.799 & 3.3199 & 1.7693 \\
\hline & III & 43.14 & 1.546 & 4.9628 & 7.1961 \\
\hline & IV & 44.93 & 1.419 & 2.5964 & 1.2001 \\
\hline & $\mathrm{V}$ & 46.12 & 1.303 & 4.0142 & 5.7627 \\
\hline & VI & 44.85 & 0.474 & 1.7002 & 1.8063 \\
\hline \multirow{4}{*}{$\begin{array}{l}\text { Black alder } \\
\text { Alnus gluti- } \\
\text { nosa } \\
\text { Fraxino- } \\
\text { Alnetum } \\
\text { Riparian al- } \\
\text { der-ash forest }\end{array}$} & I & 42.97 & 1.067 & 1.4145 & 1.2026 \\
\hline & II & 41.76 & 1.986 & 1.6451 & 1.1924 \\
\hline & III & 39.93 & 2.147 & 2.0604 & 1.2660 \\
\hline & IV-V & $\begin{array}{c}\text { no } \\
\text { data }\end{array}$ & $\begin{array}{c}\text { no } \\
\text { data }\end{array}$ & $\begin{array}{l}\text { no } \\
\text { data }\end{array}$ & $\begin{array}{c}\text { no } \\
\text { data }\end{array}$ \\
\hline \multirow{3}{*}{$\begin{array}{l}\text { Black alder } \\
\text { Alnus gluti- } \\
\text { nosa } \\
\text { Ribo nigri- } \\
\text { Alnetum } \\
\text { Swamp alder } \\
\text { forest }\end{array}$} & I-III & $\begin{array}{c}\text { no } \\
\text { data }\end{array}$ & $\begin{array}{c}\text { no } \\
\text { data }\end{array}$ & $\begin{array}{c}\text { no } \\
\text { data }\end{array}$ & $\begin{array}{c}\text { no } \\
\text { data }\end{array}$ \\
\hline & IV & 42.74 & 0.953 & 1.7863 & 0.4684 \\
\hline & V & 42.79 & 0.625 & 1.7765 & 0.9805 \\
\hline \multirow{6}{*}{$\begin{array}{l}\text { Scots pine } \\
\text { Pinus syl- } \\
\text { vestris (poor } \\
\text { habitat) } \\
\text { Leucobryo- } \\
\text { Pinetum } \\
\text { Coniferous } \\
\text { forest }\end{array}$} & I & 71.89 & 31.890 & 2.0095 & 1.2991 \\
\hline & II & 72.71 & 30.994 & 2.4879 & 0.1615 \\
\hline & III & 72.40 & 31.333 & 2.2306 & 0.4432 \\
\hline & IV & 63.39 & 29.134 & 1.7726 & 0.6527 \\
\hline & $\mathrm{V}$ & 72.84 & 30.843 & 1.7181 & 0.8584 \\
\hline & VI & 72.41 & 31.323 & 2.5061 & 0.8275 \\
\hline
\end{tabular}




\begin{tabular}{|c|c|c|c|c|c|}
\hline 1 & 2 & 3 & 4 & 5 & 6 \\
\hline \multirow{6}{*}{$\begin{array}{l}\text { Scots pine } \\
\text { Pinus syl- } \\
\text { vestris (rich } \\
\text { habitat) } \\
\text { comm. on } \\
\text { Tilio-Carpine- } \\
\text { tum habitats } \\
\text { Mixed broad- } \\
\text { leaf forest }\end{array}$} & I & 56.13 & 25.089 & 1.1835 & 1.0817 \\
\hline & II & 44.42 & 2.399 & 2.8305 & 3.7581 \\
\hline & III & 47.21 & 1.177 & 3.3170 & 1.5253 \\
\hline & IV & 64.62 & 31.529 & 2.5124 & 0.7948 \\
\hline & V & 44.43 & 0.637 & 3.5354 & 2.2461 \\
\hline & VI & 47.15 & 1.711 & 2.4509 & 0.4455 \\
\hline \multirow{6}{*}{$\begin{array}{l}\text { Spruce Picea } \\
\text { abies (lowland } \\
\text { habitat) } \\
\text { comm. on } \\
\text { Luzulo pilo- } \\
\text { sae-Fagetum } \\
\text { habitats } \\
\text { Mixed broad- } \\
\text { leaf forest }\end{array}$} & I & 39.19 & 4.121 & 0.6825 & 0.3220 \\
\hline & II & 45.04 & 1.388 & 1.2854 & 1.1101 \\
\hline & III & 43.34 & 0.622 & 1.0583 & 1.3387 \\
\hline & IV & 44.52 & 1.586 & 1.6038 & 0.9500 \\
\hline & $\mathrm{V}$ & 42.46 & 1.348 & 1.9966 & 1.9611 \\
\hline & VI & 43.71 & 0.494 & 1.7706 & 1.1382 \\
\hline \multirow{3}{*}{$\begin{array}{l}\text { Spruce Picea } \\
\text { abies (sub- } \\
\text { mountain } \\
\text { habitat) } \\
\text { comm. on Lu- } \\
\text { zulo luzuloi- } \\
\text { dis-Fagetum } \\
\text { hab. } \\
\text { Mixed broad- } \\
\text { leaf mountain } \\
\text { forest }\end{array}$} & $\leq 40 \mathrm{y}$ & 46.46 & 0.865 & 2.5498 & 2.2730 \\
\hline & $41-80$ y. & 44.44 & 1.421 & 0.8061 & 0.1235 \\
\hline & $>80$ y.o. & 44.65 & 0.797 & 0.9823 & 0.4540 \\
\hline \multirow{3}{*}{$\begin{array}{l}\text { Spruce Picea } \\
\text { abies (lower } \\
\text { mountain } \\
\text { habitat) } \\
\text { Abieti-Picee- } \\
\text { tum monta- } \\
\text { num Mountain } \\
\text { coniferous } \\
\text { forest }\end{array}$} & $\leq 40 \mathrm{y}$ & 46.25 & 0.839 & 1.6161 & 0.5901 \\
\hline & $41-80$ y. & 46.38 & 1.071 & 0.7290 & 0.5418 \\
\hline & $>80$ y.o. & 45.88 & 0.798 & 1.2088 & 0.8023 \\
\hline \multirow{3}{*}{$\begin{array}{l}\text { Spruce Picea } \\
\text { abies (upper } \\
\text { mountain } \\
\text { habitat) } \\
\text { Calamagros- } \\
\text { tio villosae- } \\
\text { Piceetum } \\
\text { Alpine conif- } \\
\text { erous forest }\end{array}$} & $\leq 40 \mathrm{y}$ & 47.71 & 1.797 & 3.3552 & 1.5964 \\
\hline & $41-80$ y. & 44.54 & 1.010 & 0.9864 & 0.2481 \\
\hline & >80 y.o. & 45.95 & 0.596 & 2.0381 & 0.0489 \\
\hline
\end{tabular}

The results of analyses show that the amount of carbon in herb and moss layer in different forest stands is very diversified. Obviously, such differences are the effects of variable soil and water conditions, and changing availability of light and other resources for under- story plants, during growth and development of main tree canopy. The highest concentrations of carbon in understory biomass was observed in pine forest stands on coniferous forest habitats. It can be interpreted as the result of most dense cover of vascular plants and mosses in undergrowth due to strong light penetration under canopy of pine forest stands in higher age classes, and additionally - as an effect of dominance in the undergrowth shrubs with partially woody stems. The relatively high concentration of carbon was observed also in the undergrowth in lowland oak and beech tree stands whose herb layer is created partly by shrubs and partly by dense grass stems and leaves containing large amounts of sclerenchyma.

Discussing the role of undergrowth in capturing carbon from the atmosphere one must not forget the fact that most of aboveground parts of stems and significant part of root systems of plants die at the end of each vegetation period, and dead leaves and stems become litter and undergo a slow decomposition. This means that annually, a part of carbon accumulated by undergrowth is translocated into the soil, and thus into another "reservoir" of carbon in the forest ecosystem.

The study showed, that carbon concentration in understory is strongly diversified, due to age of forest stand and floristic composition, and the same - due to type of forest. Forests communities are especially highly diversified, creating numerous floristic variants, facies and degenerative forms, strongly differing in species composition, plant cover and spatial structure of the understory. In general, obtained results are similar to data presented in literature for similar types of ecosystems, that means for subcontinental pine forest Peucedano-Pinetum (Banaszuk 1996; Banaszuk and Matowicka 1996), and swamp alder forests $\mathrm{Ca}$ rici elongatae-Alnetum (Czerwiński and Pracz 1995a; Pasternak-Kuśmierska and Kotowska 1995; PasternakKuśmierska and Traczyk 1995b).

A detailed study of biomass and carbon concentration of all these characters would require a huge number of trials and tests, it is therefore unlikely that in the near future such studies have been carried out. In the absence of precise details in estimating the concentration of carbon in forest undergrowth, the data provided in this paper can be a basis for more provisional estimation of carbon sequestration in herb and moss layers, on the basis of of forests in Poland. 


\section{Acknowledgements}

This research was supported by the Grant from the General Directorate of the State Forests in Warsaw, Poland, under the project "The carbon balance in biomass of major forest-forming species of Poland".

\section{References}

Apps M.J., Kurz W.A., Beukema S.J., Bhatti J.S. 1999. Carbon budget of the Canadian forest product sector. Environmental Science and Policy, 2, 25-41.

Banaszuk P., Matowicka B. 1996. Soil trophism and undergrowth layer primary production in pine forest Vaccinio myrtilli-Pinetum in Szelaggówka nature reserve in north-eastern Poland (in Polish). Zeszyty Naukowe Politechniki Białostockiej. Nauki Techniczne. Inżynieria Środowiska, 9, 101-128.

Banaszuk P. 1996. The chemical composition of the biomass of trees and undergrowth plants in wet pine forest Vaccinio myrtilli-Pinetum and fresh pine forest Peucedano-Pinetum in Szelagówka nature reserve (in Polish). Zeszyty Naukowe Politechniki Białostockiej. Nauki Techniczne. Inżynieria Środowiska, 9, 137-142.

Bhatti J.S., Apps M.J., Jiang H. 2002. Influence of nutrients, disturbances and site conditions on carbon stocks along a boreal forest transect in central Canada. Plant and Soil, 242, 1-14.

Cannell M.G. 2003. Carbon sequestration and biomass energy on the set: theoretical, potential and achievable capacities globally, in Europe and the UK. Biomass and Bioenergy, 24, 97 -116.

Czerwiński Z., Pracz J. 1995a. Content of mineral components in the herb layer plants of the alderwood Carici elongatae-Alnetum. Polish Ecological Studies, 21 (2), 171-176.

Czerwiński Z., Pracz J. 1995b. Content of mineral components in the overground parts of the herb layer plants in Tilio-Carpinetum communities. Polish Ecological Studies, 21 (2), 139-152.

Czerwiński Z., Pracz J. 1995c. Content of mineral elements in the overground parts of herb layer plants in the Sphagno girgensohnii-Piceetum community. Polish Ecological Studies, 21 (2), 195-204.
Czerwiński Z., Pracz J. 1995d. Content of mineral elements in the overground parts of herb layer plants in the community of Vaccinio uliginosi-Pinetum Kleist 1929. Polish Ecological Studies, 21 (2), 221-226.

Dyguś K.H., Traczyk H. 1995. Structural properties and herb layer production in the community of Vaccinio uliginosi-Pinetum Kleist 1929. Polish Ecological Studies, 21 (2), 213-219.

Galiński W. 1995. Carbon balance in forest ecosystems in Poland - comparison of years 1989, 1990 i 1991 (in Polish). Sylwan, 3, 31-39.

Johnson W.C., Sharpe D.M. 1983. The ratio of total merchantable forest biomass and its application to the global carbon budget. Canadian Journal of Forest Research, 13, 372-383.

Karjalainen T. 1996. Model Computations on Sequestration of Carbon in Managed Forests and Wood Products under Changing Climatic Conditions in Finland. Journal of Environmental Management, 47, 311-328.

Karjalainen T., Pussinen A., Liski J., Nabburs G., Erhard M., Eggers T., Sonntag M., Mohren G.M. 2002. An approach towards an estimate of the impact of forest management and climate change on the European forest sector carbon budget: Germany as a case study. Forest Ecology and Management,162, 87-103.

Karjalainen T., Pussinen A., Liski J., Nabburs G., Erhard M., Eggers T., Lapvetaläinen T., Kaipainen T. 2003. Scenario analysis of the impact of forest management and climate change on the European forest sector carbon budget. Forest Policy and Economics, 5, 141-155.

Kotowska J. 1995. Structural characteristics and primary production of the herb layer in Sphagno girgensohnii-Piceetum Pol. 1962 community. Polish Ecological Studies, 21 (2), 185-194.

Kurbanov E.A., Post W.M. 2002. Changes in area and carbon in forests of the middle Zavolgie: A regional case study of Russian Forests. Climatic Change, 55, 157-173.

Linder M., Sohngen B., Joyce L., Price D.T., Bernier P.Y., Karjalainen T. 2002. Integrated forestry assessments for climate changes impacts. Forest Ecology and Management, 162, 117-136. 
Muukkonen P. 2006. Forest inventory-based large-scale forest biomass and carbon budget assessment: new enhanced methods and use of remote sensing for verification. Dissertationes Forestales 30, Finnish Forest Research Institute, University of Helsinki.

Nabuurs G.J., Paivinen R., SikkemaR., Mohren G.M. 1997. The role of European forests in the global carbon cycle - a review. Biomass and Bioenergy, 13 (6), 345-358.

Nikolov N., Zeller K.F. 2003. Modeling coupled interactions of carbon, water and ozone exchange between terrestial ecosystems and the atmosphere. I: Model description. Environmental Pollution, 124, 231-246.

Pasternak-Kuśmierska D., Kotowska J. 1995. Structural characteristics and primary production of the herb layer in the Tilio-Carpinetum Tracz. 1962 community. Polish Ecological Studies, 21 (2), 127-138.

Pasternak-Kuśmierska D., Traczyk T. 1995a. Phytosorption of nutrients by the herb layer of the Tilio-
Carpinetum Tracz. 1962 community. Polish Ecological Studies, 21 (2), 153-162.

Pasternak-Kuśmierska D., Traczyk T. 1995b. Phytosorption of nutrients in the herb layer of the Carici elongatae-Alnetum Koch. 1926 community. Polish Ecological Studies, 21 (2), 177-183.

Pussinen A., Karjalainen T., Kellomäki S., Mäkipää R. 1997. Potential contribution of the forest sector to carbon sequestration in Finland. Biomass and Bioenergy, 13 (6), 377-387.

Shepashenko D., Shvidenko A., Nilsson S. 1998. Phytomass (live biomass) and carbon of Siberian forests. Biomass and Bioenergy, 14 (1), 21-31.

Turner D.P., Koerper G.J., Harmon M.E., Lee J.J. 1995. A carbon budget for forests of the conterminous United States. Ecological Applications, 5, 421-436.

Zeller F.F., Nikolov N.T. 2000. Quantifying simultaneous fluxes of ozone, carbon dioxide and water vapor above a subalpine forest ecosystem. Environmental Pollution, 107, 1-20. 